\title{
Simulation as a support tool in assembly systems planning
}

\author{
Štefan Václav $^{1}$, Šimon Lecký ${ }^{1, *}$, Katarina Senderská ${ }^{2}$ and Albert Mareš ${ }^{2}$ \\ ${ }^{1}$ Slovak University of Technology, Faculty of materials science and technology in Trnava, \\ Institute of production technologies, Slovakia \\ ${ }^{2}$ Technical University of Košice Faculty of Mechanical Engineering, Slovakia
}

\begin{abstract}
This paper deals with assumption that simulation is the only reliable method for manufacturing and assembly systems profiling. Simulation is essential software tool that improve design and planning of complex automated manufacturing and assembly systems. Systems with high level of complexity need to be tested even before they are constructed in real manufacturing plant. Elimination of errors in production before the first test production is initiated means huge savings in expenses and time. In this article are mentioned theoretical base of topic and example as a case study. For case study was used software Tecnomatix plant simulation from company SIEMENS.
\end{abstract}

\section{Introduction}

In the introduction is described the basic concept of modeling and simulation of product manufacturing and analysis of production processes. Below the model, is given a simplified picture of reality [1]. This term is used to designate a material or non-material imitation of an object, regardless of the purpose for which it is created [5].

Modeling is a theoretical and cognitive process that is based on abstracts, respectively. Ideally defined as recognizing objects through other objects that are mostly artificially created. Modeling imitates structures and behaviour of the real system [2]. Simulation of these systems is a specific form of cognitive process. The basic principle is to draw conclusions using experiments and simulations under a defined system with objects and their interactions. The basic classification of simulations can be seen in Figure 1 [4].

The simulation model can be characterized as a system that mimics the actual behavior of the simulated system. Simulation defines the artificial material objects that were created. An important element is that imitation of the system must maintain the same configuration changes over time. So, the sequence of events cannot be changed. It must be kept in simulations as it is in the original scheme [3].

"Every simulation and simulation program is now increasingly used in industrial enterprises. The pressure of competition and customer requirements are steadily increasing and therefore businesses need not to simulate production processes. Simulation programs are tools that test the effects of different model decisions and then evaluate production

*Corresponding author: simon.lecky@stuba.sk 
capacities, duration of operations, and other production parameters. They also eliminate the possibility of introducing a change into a process that would not benefit the system" [5].

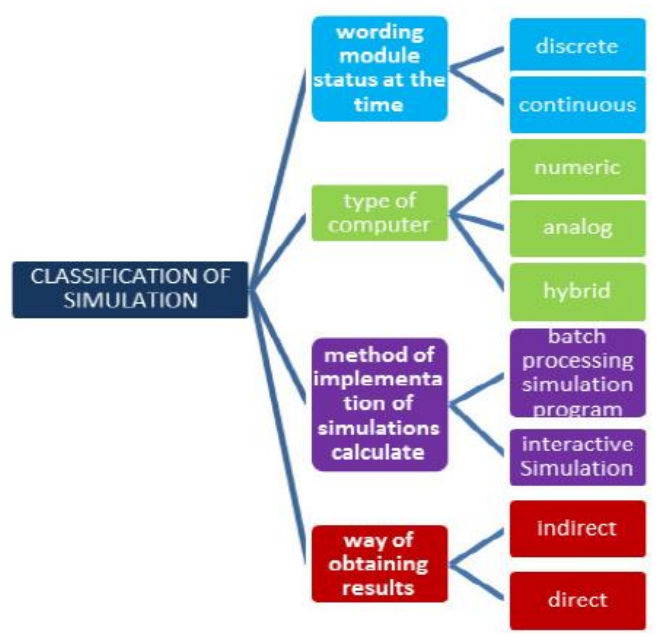

Fig. 1 Classification of simulation [12].

Simulation by Houzek R. is a numerical method that experiments with a special mathematical model [11]. Simulation is understood as a procedure, with the help of the process being studied. Respectively, its steps are generated over time, based on the parameters of the display system. The simulation model is a mathematical prescription to see these steps [10].

According to the authors of R. Debnar, J. Košturiak and I. Kurica, the main tasks of the simulation are:

- "Support for decision-making in system design and operation,

- Analysis and optimization,

- Predicting and Looking Forward,

- Replacement of the real system (training, testing, danger, etc.)" [9].

Simulation model means a mathematical technique that consists of the following elements:

- A set of logical and mathematical relationships that express the functional or other characteristics of the system,

- Include probable characteristics in the form of random effects on the model,

- Include the time for which changes are made to the model,

- There are also gradual calculations with different inputs that mimic real-time real-time behavior [8].

\section{Simulation in assembly systems and workplaces}

The simulation of workplaces and assembly systems helps in planning new systems or improving current systems (Figure 2). It is also often used in decision-making processes such as return of investment, cost of planned changes, project confirmation, production process analysis, and so on. Simulation in assembly systems facilitates the design phase and enhances the smoothness of project design and execution through its outputs. At present, simulations are up to $99 \%$ accurate. Of course, it depends on the input parameters and the validity of the model. 
Benefits of simulation:

- Testing innovative strategies in risk-free virtual environments,

- Maximum use of production resources,

- Reducing investment risk through rapid simulation,

- Optimizing the size of systems and storage space,

- Rapid identification of sources of problems in logistics and production spheres,

- $20-60 \%$ reduction in inventory due to system size,

- 5 - 20\% reduction in investment costs for the new system,

- Reduction of capacities for personnel and handling equipment,

- Quickly achieve positive results and identify impacts [7].

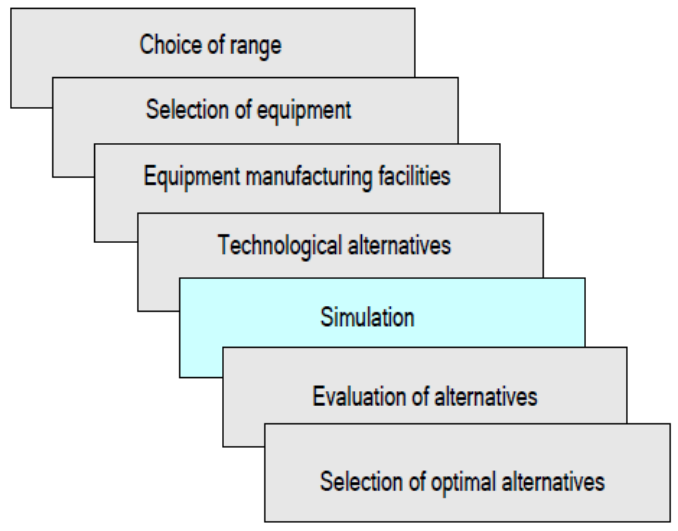

Fig. 2 Integration of simulation in designing of production cells [5].

Simulation of assembly sites is currently being used in robotic positions or in the area of cooperative stations. Similarly, software for simulating staff movements, examining workplace ergonomics, or testing the load on a worker's spine while working with loads is also widely used. Examples of such software can be Tecnomatix Process Simulate for simulation of robotic workplaces or Tecnomatix Jack for simulation of human factors and ergonomics.

\section{Example of simulation and analysis in assembly system}

This section discusses an example of a design and analysis of an assembly system consisting of three assembly workplaces, one control stand, one conveyor and one buffer (Figures 3 and 4). Simulation as a tool that helps analyse assembly systems allows assembly systems to improve without interruption of production. The Tecnomatix Plant Simulation software from SIEMENS was used to model and simulate the assembly system.
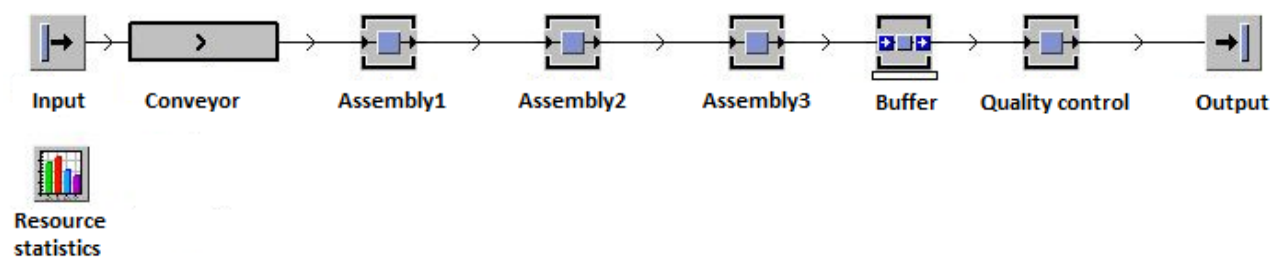

Fig. 3 Base model of assembly system. 


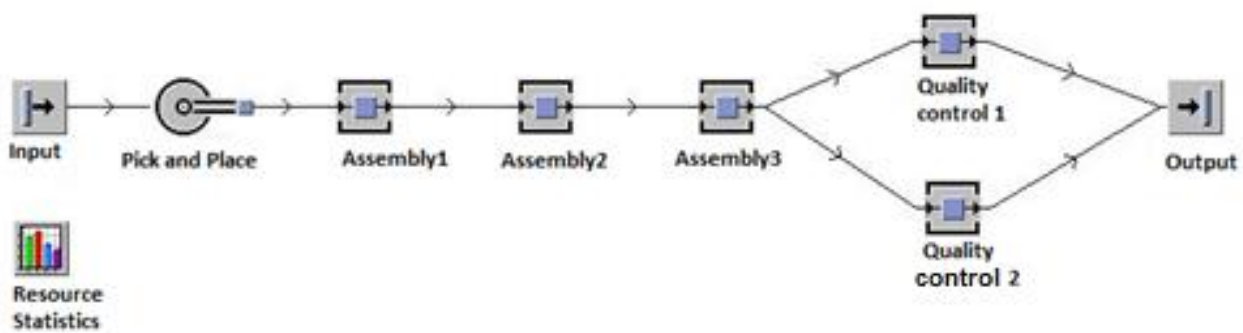

Fig. 4 Customized model of assembly system.

When analysing the assembly system, it was assumed based on the time pool of individual positions that the bulk will accumulate before the inspection position. After analyzing the model simulation results, it was found that 399 products were produced after eight hours of assembly time. Against the basic model where there were 149 products made after eight hours are 250 pieces more products. This means an increase in productivity by $267.78 \%$.

Based on the source statistics, it is possible to see how the model of the assembly system differs before and after the adjustment, Figure 5. Mounting position number three is not blocked after the simulated model has been modified, and the addition of a further control opinion has reduced the control load and allowed for better system throughput.
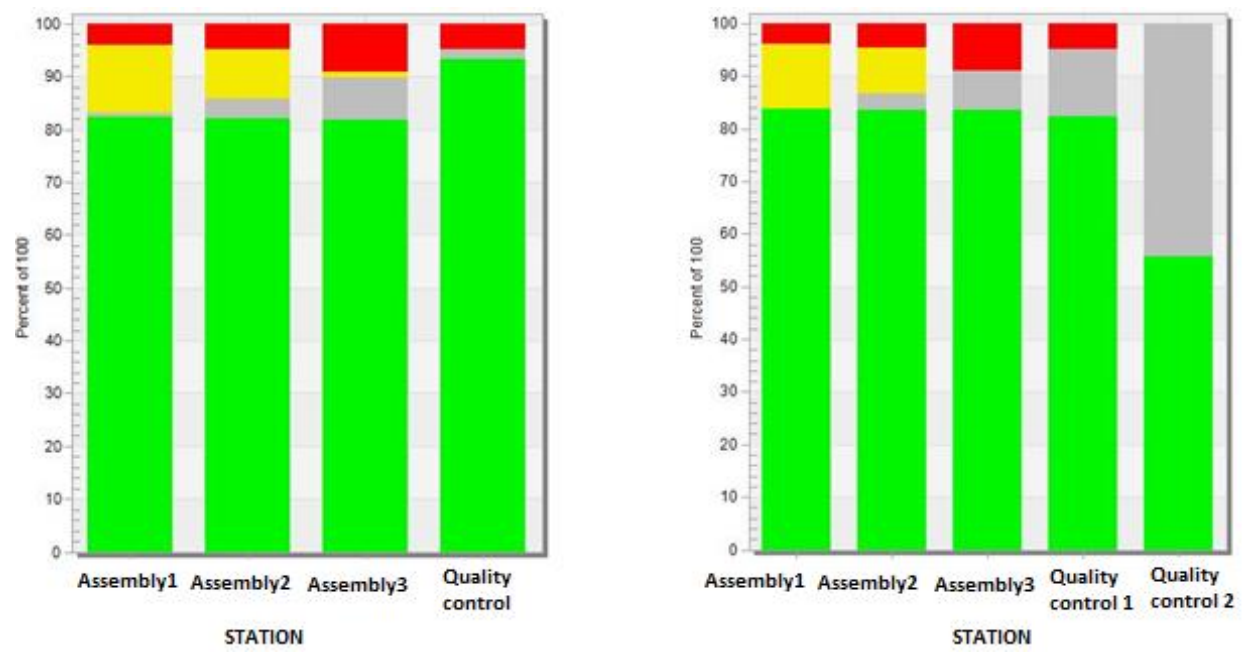

Fig. 5 Resource statistics - Base model (left), Customized model (right).

Legend: Work

Blocked

Failure

\section{Conclusion}

At present, simulation is increasingly used in assembling and especially in the development phase of assembly workplaces and systems. The use of simulations is mainly driven by the simulation benefits that are mentioned in the article. The main advantages of assembly simulation are to shorten development times, to eliminate design errors in assemblies before putting them into operation, to test several versions of assembly systems or workstations. An example simulation of the assembly system was done in the Tecnomatix 
Plant Simulation software, and a proposal to improve the assembly system was introduced. Results shown that throughput of the assembly system was increased by $267.78 \%$.

Gradually, as IT advances in the world, simulations are becoming increasingly prominent and assembly simulation can be expected to be one of the core tasks of development teams.

The article was written as part of the VEGA 1/0477/14 project "Research of influence of selected characteristics of machining process on achieved quality of machined surface and problem free assembly using high Technologies" supported by the scientific grant agency of the Ministry of Education of the Slovak Republic and of Slovak Academy of Sciences.

\section{References}

1. L. Réveszová, D. Pal’ová, Základy modelovania podnikových procesov, Košice, Technická univerzita v Košiciach (2009)

2. S. Klos, J. Patalas-Maliszewska, Management and Production Engineering Review (2013)

3. M. Gregor a kolektív, Simulácia systémov, Žilina, Vysoká škola dopravy a spojov v Žiline (1992)

4. D. Malindžák: Modelovanie a simulácia v GPSS, Košice (1988)

5. L. Pachniková, L. Šidlovská, Simulation as support tool for design of manufacturing systems, Transfer inovácií 18 (2010)

6. M. Straka, D. Malindžák, Acta Montanistica Slovaca 14 (1) (2009)

7. TECNOMATIX Plant Simulation, Product overview, SIEMENS (2016)

8. J. Burieta, Simulácia. In Ipaslovakia (2007)

9. R. Debnár, J. Košturiak, I. Kuric, Simulácia ako nástroj pre zvyšovanie produktivity a zisku podniku (2016)

10. M. Houška, Simulačné modely I. Praha: Česká zemědělská univerzita v Praze. (2005)

11. T. H. Naylor, D. S. Burdick, K. Chu, Computer Simulation Techniques. New York (1968)

12. P. Trebuňa, M. Kliment, Edl, M., M. Petrik, Creation of simulation model of expansion of production in manufacturing companies. Modeling of mechanical and Mechatronic Systems MMaMS (2014). 
